\title{
The Gender Divide in Issue Attention ${ }^{\mathrm{i}}$
}

\author{
Laura Chaqués-Bonafont \\ Political Science Department \\ Universitat de Barcelona - Institut Barcelona d'Estudis Internacionals \\ laurachaques@ub.edu \\ ORCID 0000-0002-0724-4871 \\ Camilo Cristancho \\ Political Science Department \\ Universitat de Barcelona \\ camilo.cristancho@ub.edu \\ ORCID 0000-0003-1794-4457
}




\begin{abstract}
This article explores the conditions under which female MPs are more likely than male MPs to participate in political debates relating to a range of issues. Building on descriptive representation theory and parliamentary behaviour studies, we examine how the effect of the number of women in parliament, and women's access to leadership positions, on MPs' issue attention varies across policy areas and parliamentary venues. Looking at oral questions asked by male and female MPs in plenary sessions and parliamentary committees in Spain from 1982 to 2018, we found that numbers and leadership positions significantly affect female MPs' attention to those parliamentary activities that aim to highlight the merits of government action and in venues that are less open to public scrutiny. Our results also illustrate that the presence of women in parliament and their access to leadership positions have a significant impact on female MPs' attention to rights- and welfare-related issues, but not issues traditionally linked to high-profile political areas such as national security, macroeconomic policy and government affairs. The presence of women in parliaments has increased globally, but inequalities in the gender distribution of issue attention persist, thereby reducing the capacity of female MPs to act on behalf of and stand up for women in political debates on most issues.
\end{abstract}

Key words: Political representation, agenda setting, gender, parliamentary behaviour 


\section{Introduction}

Women's presence in parliament has increased in most advanced democracies. A large number of scholars have analysed the link between the increasing presence of women in politics and women's ability to symbolically represent female voices in the political debate, and/or to act for women in a manner that is responsive to them (Pitkin, 1967; Mansbridge, 1999; Saward, 2008; Celis and Childs, 2008; Lovenduski, 2005). Overall, these studies have found that descriptive representation does not automatically translate into a symbolic and/or substantive representation of women preferences (Waylen et al., 2013). Most of these studies (see Paxton et al., 2007 or Wängnerud, 2009 for a review) focused mainly on the conditions under which an increasing number of women alters the capacity of female MPs to promote issues that directly affect, or that are traditionally associated with women, but did not reveal much about their ability to participate in the political debate across issues (Lombardo and Meier, 2016).

This is problematic, since female MPs in most advanced democracies occupy marginal positions in political debates concerning many issues, especially those that are more rewarding in political terms (Studlar and Moncrief, 1999; Escobar-Lemmon and Taylor-Robinson, 2009; Annesley et al., 2015, 2019; Blumenau, 2019). Despite the increasing presence of women in parliament, male MPs continue to dominate political debates on most issues, especially so-called hard issues such as macroeconomics, foreign and government affairs, while female MPs tend to focus their attention on socalled women's issues, including gender violence, labour market inequalities and family matters. The underrepresentation of women across policy domains has important implications for political representation in two major interconnected areas. On the one hand, they reduce the ability of female MPs, as legitimate, relevant political actors, to stand up for women and symbolically represent women's voices in discussions on a wide range of issues. On the other hand, they reduce the capacity of female MPs to act 
on behalf of women by including a gender perspective in political debates on most issues (Lombardo and Meier, 2016). Women's life experiences differ from those of men, and this affects not only women's perception of the issues that merit political attention, but also the way in which females understand and frame issues beyond socalled women's issues.

Thus, the question we pose in this paper relates to the conditions under which female MPs are more likely to participate in political debates across issues. Gender scholars have highlighted that the number of women in parliament matters (e.g. Dahlerup, 1988; Saint-Germain, 1989; Thomas, 1991, 1994; Bratton, 2005). In particular, Atkinson (2020) demonstrated that the more women serve as MPs, the more diverse the female agenda will become. However, we argue the presence of women in parliament per se may have no impact on the representation of women if there is no transformation in the embedded culture of masculinity that has traditionally dominated political institutions (Lovenduski 2001, 2005; Heath et al., 2005 among others). The capacity of female MPs to stand up and act for women across a wide range of policy domains depends not only on bringing women into parliament, but also on transforming the way in which political institutions function (see Dahlerup, 2006; Krook 2010; Murray 2014, Welzel et al. 2002:144; Mateo-Diaz, 2005; Delgado, 2012; O'Brien and Rickne, 2016).

This paper contributes to this literature by demonstrating that female MPs participate less in parliamentary debates dealing with highly salient issues, especially those most citizens identify as the most important issues for the nation. As in the case of Latin America (Heath et al. 2005), the US (Atkinson (2020), or the UK (Blumenau 2019), the paper shows that gender bias persists despite the increasing presence of women in Parliament, and their appointment to leadership positions within political 
institutions, such as chairs of parliamentary committees and cabinet ministers. The paper also demonstrates the increase in the number of women in Parliaments and leadership positions has a larger effect on the ability of female MPs to participate in political debates for MPs on right-wing parties, and in the case of MPs of the governing party. This implies that female MPs' share of issue attention is greater during periods in which the party is supporting and praising the action of the government of which it forms a part, rather than opposing the government. Finally, the paper demonstrates the ability of women to participate in political debates is greater in venues that are less open to public scrutiny and, hence, less rewarding in political terms.

The empirical analysis focuses on Spain over the last 36 years, a period that covers the democratic consolidation in 1982 up to 2018. This case is particularly interesting in a European perspective, since Spain evolved from one of the countries with the fewest women in parliament in the early 1980s to one of the countries with the highest percentage of women in parliament in 2018 , at almost $50 \%$. This provides a unique scenario in which to test the importance of institutional factors and party preferences for descriptive representation and, more precisely, for the gender divide in issue attention in parliament. The article relies on data on oral questions asked by MPs in plenary and committee sessions, and the structure and composition of parliamentary committees and the government.

The paper is structured as follows. The first section sets out the theoretical argument and defines the main hypotheses that underpin the rest of the paper. The second section provides a detailed description of the empirical strategy and broadly outlines the case of Spain. The third section presents the results of the statistical analyses, and the final section discusses the findings in light of the importance of attention differences to equal representation between the genders. 


\section{Representation of Women's Preferences}

The relationship between descriptive, symbolic and substantive representation has been subject to long, intense theoretical and empirical debate (Pitkin, 1967; Lovenduski, 2005; Lombardo and Meier, 2016). In the Burkean tradition, the characteristics of representatives per se are not relevant to substantive political representation. What matters is that the ideas and preferences of those represented are considered in the political debate, regardless of who represents these ideas and preferences (see Pitkin, 1967; Dahl, 1998; Schwindt-Bayer and Mishler, 2005, for a discussion). In this regard, women's presence in parliament is not a prerequisite for the representation of women's preferences.

This is problematic for several reasons. On the one hand, female and male policymakers have different life experiences, values and concerns, and these differences affect the way in which they prioritize and frame policy issues (Phillips, 1995; Mansbridge, 1999; Chattopadhyay and Duflo, 2004; Lovenduski, 2005; Dingler et al. 2019). Early studies argued that female MPs act on behalf of women because they highlight issues that reflect the structural exclusion of women from most arenas of socio-economic or political power (Phillips, 1995). These studies tended to identify women's preferences with women's issues, defined as issues that affect women directly or those that are intended to do so (Saint-Germain, 1989; Thomas, 1991; Jones, 1997; Burns and Gallaguer, 2010; Bratton, 2005; Childs, 2004; Taylor-Robinson and Heath, 2005, among others). In most cases, women's issues are defined ad hoc as the issues raised by female MPs.

Yet this connection between women's preferences and certain issues is problematic for a number of reasons. First, women's preferences are not biologically driven or homogeneous, but social constructions, which, by definition, are not grouped 
identically and vary greatly over time and across countries (Burns and Gallagher, 2010:426; Bratton, 2005). There is no single list of issues that reflect women's preferences over time and across social groups, parties and countries. Second, different life experiences affect not only women's perceptions of the issues that deserve political attention, but also the way in which women understand and frame issues ranging from gender violence to agriculture, defence and foreign affairs. To introduce a gender perspective, female MPs are required to participate in the political debate across a range of subjects, beyond so-called women's issues.

On the other hand, political representation is not only about acting for women but also about standing up for women in the public sphere (Schwindt-Bayer and Mishler, 2005; Lombardo and Meier, 2016). Women should access the parliamentary arena and actively participate in the political debate to guarantee that women are represented both literally and symbolically and, more broadly, to overcome male domination in the public sphere. The problem is that in most advanced democracies women are underrepresented across policy domains (see Studlar and Moncrief, 1999; Escobar-Lemmon and Taylor-Robinson, 2009; Celis et al., 2016; Annesley et al., 2019; Blumenau, 2019; Barnes and O'Brien, 2018). Female MPs occupy a marginal position in political debates on many issues, especially those that are more rewarding in political terms, with a few exceptions (see Osborn and Mendez, 2010). Male policy domains relate to so-called "high profile" or hard issues, such as macroeconomics, foreign affairs and general government affairs, while female issues relate to "low profile" or soft issues, which include education, health, and everything related to the so-called women's issues like child bearing, sexual harassment and violence, labour market inequalities, the unequal division of paid and unpaid labour and general family matters (Krook and O'Brien, 2012). This gender divide in issue attention is problematic because it limits the 
ability of female MPs to act on behalf of women and therefore introduce a gender perspective into the political debate across issues.

\section{Participation in Parliamentary Debates}

The question then is what conditions are required to reduce gender differences in issue attention? Existing research has pointed to the importance of the number of women in parliament (e.g. Dahlerup, 1988; Saint Germain, 1989; Thomas, 1991, 1994; Bratton, 2005). Overall, these studies suggest that the focus on women's issues tends to increase in parliaments with a higher number of female MPs. In many cases, this is a result of an accumulative process in which each female MP makes a contribution, introduces a bill, asks a question to members of the government or carries out any other parliamentary activity relating to a "women's issue" (Atkinson and Windett, 2019). Also, these studies show that a greater presence of women in parliament affects the intensity to which female MPs get involved in parliamentary activities (Blumenau 2019), and the range of issues they deal with over the course of the term (Atkinson 2020). In this context, we expect

H1: Female MPs' attention to issues will increase as the number of women in parliaments increases.

However, numbers alone cannot bring about substantive changes in the existing gender divide in issue attention. Formal and informal rules and codes of conduct relating to the way in which parliaments function affect the ability of women to get involved in political debates about certain issues, especially those that are more rewarding in political terms and are traditionally driven by male MPs (Grey, 2002; Celis, 2012; Heath et al., 2005; Annesley et al., 2019). In this regard, authors such as Lovenduski $(2001,2005)$ have argued that women's ability to participate in the debate on "male" issues such as the economy, defence and terrorism depends not only on the 
presence of female MPs in parliament, but also on the importance of male-dominated networks, and the embedded culture of masculinity in political institutions. Female MPs perform political activities in a political context that is functionally adapted to men in terms of bargaining rules and professional networks (Franceschet and Piscopo, 2008). In this context, the ability of female MPs to act on behalf of and stand up for women depends on whether their presence is accepted and progressively internalized in political institutions that traditionally function in accordance with a culture of masculinity.

A substantial number of studies have already demonstrated how political institutions are gendered to women's disadvantage in most advanced democracies (Galligan, 2007; Galligan et al., 2008; Childs, 2004; Darcy, 1996). Using the case of six Latin American countries, Heath et al. (2005) demonstrated that the presence of women in parliament does not prevent female MPs' being restricted to committees focusing on women's issues and social issues. To the contrary, female MPs are kept away from highprofile issues and committees mainly when committee assignments are controlled by male party leaders, and when the structure of the committee system provides a specific committee to deal with women's issues. By the same token, Escobar-Lemmon and Taylor-Robinson (2009) demonstrated that presidential cabinets in Latin America are gendered institutions that systematically reinforce gender differences in issue attention. Women are underrepresented in masculine domains like agriculture, public works, defence, finance, foreign affairs, government and the interior, and overrepresented in feminine domain portfolios, mainly health, education, and social welfare. Authors like Studlar and Moncrief (1999) in the case of Canada, and Annesley and her coauthors (2019) in the case of Australia, Canada, Chile, Germany, Spain, US and the UK reached similar conclusions. We thus expect that: 
H2: Female MPs' attention to high profile issues is less likely to increase than low profile issues as the number of women in parliament increases.

Changes in the way political institutions function require time and are usually subject to intense intra- and inter-party competition, as in the case of women's access to leadership positions (Mattson and Strom, 1995, 2004; Damgaard, 1995; Döring, 1995; Cox and McCubbins, 2005). In most countries, women's access to political institutions occurs gradually as regulatory changes, such as gender quotas, are adopted (Murray, 2014; Krook, 2010, Lovenduski et al. 2006). Positive discrimination and affirmative action strategies affect women's eligibility to run for elected office and hold leadership positions in government and parliament (Welzel et al., 2002; Meier, 2004; Mateo-Diaz, 2005; Verge and de la Fuente, 2014; Delgado, 2012; O’Brien and Rickne, 2016). They are designed to transform formal political institutions towards more gender-balanced environments, thereby generating positive spillovers and changing perceptions concerning the abilities of female MPs in the parliamentary setting.

MPs' access to leadership roles within parties and in parliament increases their capacity to select the issues they address, the way in which they talk about these issues and the venue in which they voice their policy preferences (e.g. Döring, 1995;; Cox and McCubbins, 2005). Moreover, access to leadership positions conveys a message that women are capable of leadership and that they can be a voice of authority and credibility in a particular policy domain (Franceschet and Piscopo, 2008; Heath et al., 2005). Female MPs will thus become more accepted as legitimate policy actors across different policy domains, thereby transforming the way in which political institutions function.

Authors such as Matland and Studlar (1996) and Gilardi (2015) point out that an increasing number of women in leadership positions may also lead to a "contagion" 
effect in terms of female leadership and political participation across parties and policy domains. Once a woman is appointed as a minister or chair of a parliamentary committee, rival parties may feel pressured into appointing women to participate in parliamentary debates. Empirical research has already provided some evidence that women's access to leadership positions has brought about substantive changes in the existing gender divide in issue attention (Gilardi, 2015; Blumenau, 2019; Bäck and Debus, 2019; Krook and O’Brien, 2012). In particular, Blumenau (2019) demonstrated that the appointment of female cabinet ministers in the UK has increased the participation of female MPs in parliamentary debates regarding particular policy areas. According to the above discussion, we expect:

\section{H3: Female MPs' issue attention will increase as women are appointed to} leadership positions in parliamentary committees.

\section{H4: Female MPs' issue attention will increase as women are appointed to} leadership positions in the executive, such as ministers.

In addition to the potential effects of women in leadership positions, we also expect to find institutional differences between parliamentary venues. The masculine culture is less likely to be transformed in plenary sessions than in parliamentary committees for a number of reasons (e.g. Döring, 1995; Mattson and Strom, 1995). The plenary session is the most exposed aspect of parliamentary work. This is the venue for most of the important parliamentary tasks, including preliminary debates on legislative proposals, enactment of legislation and oversight of political debates. In contrast to parliamentary committees, activities that take place during plenary sessions are highly visible and open to public scrutiny, as they are broadcast in the media and, in recent times, have been shown on live webcasts on the parliament's website. Hence, plenary sessions are the most rewarding venue in political terms. Individual MPs are eager to participate in 
plenary sessions to discuss the most critical issues of the day as a means of raising their visibility among the electorate and party leaders and, more broadly, of advancing their political careers. Therefore, the male hold over plenary sessions is likely because of the intense competition for attention. Accordingly, one may expect:

H5: Female MPs' access to political debates will be greater in committee sessions than plenary sessions.

\section{Data and Methods}

We put our expectations to the test by analysing oral questions in plenary and parliamentary committee sessions between 1982 and 2018 in the Congreso de los Diputados (the lower house in Spain) ${ }^{\mathrm{ii}}$. Oral questions are asked by individual MPs on a regular basis, usually every week during parliamentary sessions. In formal terms, oral questions are one of the main tools available to members of parliament to scrutinize the executive's actions. However, oral questions are also usually important attentionseeking devices that policy actors use to raise the visibility of the issues they identify as policy priorities. Yet, as in other parliamentary democracies with strong party discipline, the capacity of individual MPs to use oral questions as attention-seeking devices is determined by parliamentary groups, which act as key veto players by imposing significant limitations on which MPs can participate and what they can do during question time (Russo and Wiberg, 2010).

The number of oral questions allowed per session for each parliamentary group varies across legislatures, depending on the number of seats held by each group. In practical terms, this means that most oral questions are asked by two political parties (i.e. PSOE and PP), which accounted for more than $80 \%$ of the seats up until 2015 (see Table A1 in the Appendix). According to the rules of parliament, any deputy can ask questions to members of government. However, those deputies that are also members of 
government (ministers and vice-ministers) never ask oral questions in the parliamentary arena. Finally, in contrast to other countries (see Russo and Wiberg 2010, ChaquésBonafont et al. 2015, Chaqués-Bonafont and Palau 2011), the governing party asks an important percentage of oral questions, especially during the period 1996 to $2008^{\mathrm{iii}}$. A reform of parliamentary rules, along with the economic crisis in 2008 , led to a decline in the number of oral questions asked by the governing party (see Chaqués-Bonafont et al. 2015).

\section{Female Issue Attention}

We aggregated questions on a monthly basis in order to consider attention limits and agenda capacity. Female issue attention was measured as the percentage of questions asked by female MPs on a particular issue each month as a fraction of the total number of questions asked by male and female MPs on that same issue in that month. We chose an aggregate measure as we are interested in the overall effect of female attention, rather than on the individual behaviour of MPs. Our period of analysis covered 352 months of sessions in the Congreso de los Diputados between 1982 and 2018. During this period, 21,329 questions were registered in the official congress records. We assigned these questions to 14 issues by aggregating the 21 major topics in the Comparative Agendas Project (See Baumgartner, Breunig and Grossman, 2019; Baumgartner and Jones, 1993). The aggregation of issues into 14 policy areas follows the division of policy areas across ministries. Furthermore, as in many other parliamentary democracies, parliamentary committees follow a similar division of labour as the structure of government ${ }^{\mathrm{iv}}$ (Table A9 in the Appendix). The classification of questions into policy topics resulted in 3,857 observations by issue-month. The mean number of questions per issue each month was 5.37 (SD 5.13), and February 2012 was a record month in which 55 questions relating to national security issues were asked. The 
number of questions varies proportionally to the number of sessions per month and issue salience. Consequently, peaks in issue attention, government scandals or intense parliamentary activity result in a higher number of sessions.

\section{Numbers, Leadership and Venue}

The number of women was calculated based on the percentage of female MPs in the Congreso de los Diputados in each of the 10 legislatures between 1982 and 2018. This percentage increased gradually from about $5 \%$ in 1982 to almost $50 \%$ in 2018 , one of the highest percentages seen in advanced democracies. In the early 1990s, the far-left party Izquierda Unida (IU) and the PSOE introduced compulsory quotas into their internal structure and electoral lists (Delgado, 2012; Mateo-Diaz, 2005; Verge, 2008). As a result, the percentage of female MPs in 1996 was almost 21.6\%, although there were significant differences between political parties. In the late $1990 \mathrm{~s}$, the percentage of female MPs in the PSOE was almost double that of the PP. These differences between right-wing and left-wing parties disappeared only in the late 2000s, after Organic Law 3/2007 of 22 March, for Effective Equality between Women and Men, was passed in 2007. This law established, among other things, a fixed quota of female MPs in electoral lists (see Verge and de la Fuente, 2014 and Delgado, 2012 for a review). We used three indicators to explain the influence of female leadership in political institutions on female attention: the number of female MPs in parliamentary committees, the number of female MPs who held chair or vice-chair positions in parliamentary committees, and the presence of female ministers.

Each committee has one chair and two vice-chairs, with some minor exceptions $^{\mathrm{v}}$. All parliamentary groups may have the role of chair and vice-chair. As an example, in the $14^{\text {th }}$ legislature (2020-) the PSOE holds $47.5 \%$ of Committee chairs, the PP the 22.5\%; Unidas Podemos the $17.5 \%$, ERC the $7.5 \%$, and the PNV, and the "grupo 
plural" hold one committee chair each. According to the rules of the Congreso de los Diputados (art. 33), vice-chairs perform the same functions as the chairs in the event of vacancy, absence or incapacity, and carry out any other functions entrusted to them by the Chair. In most cases, this means that vice-chairs lead one of the subpolicy areas the commission is dealing with. The number of women in parliamentary committees reveals the degree to which the presence of female MPs in parliament has been normalized. As explained above, what matters is not only that the number of women in parliament is increasing, but that their presence is evenly distributed across political institutions that traditionally function in accordance with a culture of masculinity. We aimed to use this variable to understand the extent to which variations in the number of women in a parliamentary committee in a particular policy area affect female issue attention in that particular policy area (e.g. female MPs who hold $50 \%$ of the plenary seats, but only $20 \%$ of the defense committee seats).

Committee membership and chair positions among female MPs were identified using a dataset on the parliamentary committee composition of the Congreso de los Diputados from 1982 to 2018 (available at www.q-dem-com). This dataset provides information on committee functions, composition (in terms of gender and number of deputies per party), type (permanent or non-permanent) and the roles performed by each deputy over time, and makes a distinction between four types of role performed by MPs: chair (or co-chair), speaker, secretary and member. The committees were classified according to the same 14 issues as the oral questions with a view to measuring the share of female MPs who were members of the committee on the same issue on a monthly basis. A similar indicator was used to measure the share of female committee chairs or vice-chairs on the issue by month. Although the two indicators were highly correlated (alpha $=0.92)$, we tested the extent to which chair positions differed from 
regular committee membership. Since we were also interested in female leadership in government, we identified whether the minister to whom the oral question was addressed was a woman. We also divided ministerial portfolios into the 14 issues to identify whether the minister dealing with the issue each month of the analysis was a woman. This was the case $20 \%$ of the time: there were 771 issue-months with female ministers and 3086 with male ministers.

Regarding the potential differences between venues, we split the data into committee venues $(64.4 \%)$ and the plenary $(33.6 \%)$. The former includes all oral questions to members of government dealing with a particular policy area by individual MPs in a parliamentary committee, while the latter includes all questions asked in plenary sessions to members of government. Finally, we also expected issue attention to be influenced by parliamentary institutions and specific country characteristics, such as partisan dynamics and historical factors. We thus controlled for the following factors in our analyses: (1) gender quotas, by treating separately the period from 2008 to 2018 (as defined above); (2) temporal effects, by introducing fixed effects by legislature; (3) agenda capacity, by considering the number of questions per session and the number of sessions per month; (4) ideology and (5) incumbency status.

We measured party ideology using expert data on a general left-right scale $\left(\right.$ Bakker, et al. 2020) ${ }^{\text {vi }}$. We split parties with an ideology score of less than 5 into leftwing parties (43.8\%) and those with a score higher than 5 into right-wing parties (46.2\%). Five percent of the questions, which were asked by MPs in the smaller parties belonging to the "mixed group", were excluded from the analysis, since this group consisted of parties with both left-wing and right-wing ideologies. Given that our analyses were aggregated on a monthly basis, we used month-issue-ideology as our unit of analysis for this part of the study. This resulted in 6,621 observations. The analyses 
of issue attention across venues and incumbency status followed a similar logic. We split our sample into incumbent (36\%) and opposition (64\%) parties. Incumbent status is especially relevant given that the Spanish system tends to be bipartisan in nature. The conservative PP party and the socialist PSOE party accounted for more than $80 \%$ of the seats from 1982 to 2015 and have alternated in office for the whole democratic period. Most importantly, their share of questions was the same for most of the period under analysis. Descriptive statistics are presented in Table A1 and Figure A1 in the appendix.

\section{Findings - The Decline of Gender Differences in Issue Attention}

\section{Numbers}

At first glance, our data showed an increase in female attention over time for most issues. Figure 1 shows the share of attention of female MPs to issues in relation to that of male MPs (blue line) and the share of female MPs in parliament (green line).

However, it also highlights the considerable variation in the distribution of female MPs' attention to issues across policy areas. On the one hand, there is only one policy area, i.e. justice, in which female MPs dominated the political debate for almost the whole period. The justice debate includes all rights-related issues, including abortion, gender discrimination and prostitution, and issues related to child abuse, sexual harassment and gender violence (see Table A9 in the Appendix). In contrast to other policy areas, the share of female attention to justice grew rapidly during the 1980s and, by the mid$1990 \mathrm{~s}$, it had reached a similar level to that of male MPs.

On the other hand, Figure 1 illustrates increasing levels of female attention to women's issues, especially social policy, which includes issues relating to labour market inequalities, the unequal division of paid and unpaid labour, general family issues and, to a lesser extent, health and education policies. Female MPs' share of attention also increased in so-called male issues, but this increase did not prevent 
women from occupying a marginal position in political debates on issues such as commerce and banking, macroeconomic policy, national security, foreign policy and government affairs, even after the implementation of gender quotas in the late 2000s. Female MPs' share of attention with respect to male issues was relatively low and, in most cases, was limited to specific aspects of these policy areas, such as human rights and cooperation in the case of foreign policy.

Figure 1. Attention of Female MPs Over Time by Issue

To explain gender differences in issue attention across time and policy areas, we regressed female attention on numbers, which were measured using two different indicators (the share of female MPs and the share of female MPs in each parliamentary committee); leadership, which was measured using two different indicators (the share of female chairs and vice-chairs in each committee by policy area and a dummy variable that identified those periods in which the minister dealing with the issue was a woman). In these models we controlled for the potential effects of agenda capacity (number of questions and sessions per month) or temporal effects (fixed effects by legislature) and gender quotas (2008-2018). We ran independent models for each covariate in order to avoid collinearity problems (Table A2 in the Appendix) and additional models for ideology and incumbency status.

Results of the independent OLS models are presented together in Figure 2, and the complete results are available in Models $1-4$, Table A3. The share of women in parliament is the strongest predictor of female MPs' issue attention. The positive and significant coefficient in Model 1 reveals that the issue attention of female MPs increased as the number of female MPs in parliament rose, as expected in H1. As Atkinson (2020) demonstrated for the US and Blumenau (2019) demonstrated for the 
UK, these results confirm that the presence of more women among the political elite improves women's access to the parliamentary floor.

However, these results also highlight that simply winning a larger number of seats in parliament for women is not enough to overcome female MP underrepresentation in the political debate for many issues, especially high-profile issues. Figure 3 shows the estimates broken down by policy area (full results in Table A5). Female attention to issues related to health, justice, labour, foreign affairs, and social policy increased as the share of female MPs increased, but this was not the case for agriculture, commerce, economy, education and culture, environment, and governmental affairs, for which the coefficients were positive but not statistically significant. This finding supports our second hypothesis: female MPs' share of attention significantly increased for most of the so-called women's issues (with the exception of foreign affairs), but this increment was non-significant for masculine issues. The presence of women has been accepted, and even reinforced in those policy areas traditionally associated with women's issues, or those in which women gain professional expertise in and out of the private sector (e.g. women's advancement in the legal profession), while the opposite is the case in macroeconomics or finance where female experience is still low (see also Annesley et al., 2019).

Figure 2 and 3 about here

\section{Leadership}

With respect to our expectations of leadership, the results also reveal that female MPs' share of issue attention increased as they obtained leadership positions. As expected in H3, during periods in which a woman was appointed chair or vice-chair of parliamentary committees, female MPs' share of issue attention increased. The results also support hypothesis 4 , as the same occurred when a woman occupied ministerial 
positions relating to the issue. Positive and significant coefficients in the aggregate models (Figure 2 and Models 2 and 3 in Tables A3 and A4) show that the percentage of oral questions asked by female MPs about a particular policy area increased as women acquired leading positions in government and parliament. However, there were some important differences across policy areas. As in the case of "numbers", "leadership" in parliamentary committees significantly affected female attention to issues in so-called women's policy areas, but not in policy areas traditionally linked to male domains, with the exception of foreign affairs (Figure 3 and Table A5).

Figure 4 further illustrates this trend. It shows the patterns of female issue attention during periods in which women held ministerial portfolios and committee chairs. Female attention tended to increase during periods in which a woman was appointed as a cabinet minister for that particular area, but this increase was significant only in the case of the environment, agriculture and, above all, defence. After the first female minister of defence, Carme Chacón, was appointed in 2008 during PSOE leader José Luis Rodríguez Zapatero's second term, the share of female MPs' attention to defence issues in parliamentary debates continued to grow steadily until it reached more than $50 \%$ of the agenda. In contrast, the appointment of women to leadership positions seems to have had no significant impact on women's issues or on male issues such as commerce and banking, the economy and government affairs.

\section{Figure 4 about here}

These results held after quotas were implemented in the general elections of March 2008. Coefficients were positive and significant in the case of leadership before and after the implementation of gender quotas, but the effect of parliamentary leadership was slightly lower. With a higher share of female MPs in parliament, the effect of occupying committee seats seems to be less relevant in explaining issue 
attention. In contrast, once quotas were introduced in 2008, coefficients were not significant in the case of "numbers". This result seems to indicate a threshold effect. Once the share of women reaches a third of parliamentary seats and grows at a much lower rate, the number of female MPs does not affect the share of female MPs' issue attention.

\section{Venue}

Finally, we expected to find differences in the impact of numbers and leadership depending on the venue in which the oral questions were asked. We estimated female issue attention based on interactions by plenary sessions vs. committees (Figure 5 and Table A6). Our results demonstrate that the positive effect of the number of women in parliament on their ability to ask oral questions is stronger in committees than in plenary sessions. On the other hand, the results indicate that there is no difference between venues regarding the effect of female committee chairs or ministers on the number of oral questions female MPs ask. These results give partial support to our fifth hypothesis. Closing the gap on the existing gender divide regarding issue attention is more likely in those venues that are more policy-oriented, more focused on drafting legislation and generating political consensus, and in general, less open to public scrutiny.

\section{Figure 5 about here}

When controlling for party ideology (Figure A2 and Table A7), we can see that the effect of numbers is pushed mostly by female MPs from leftist parties. With respect to female leadership, the evidence suggests that female MPs from right-wing parties depend more on the normalization of women in parliament than those from left-wing parties. That is, female MPs in ministerial positions and leadership roles in committees have a stronger effect on right-wing female MPs than left-wing female MPs. The results 
for the 2008-2018 period show that there were slight changes in the magnitude of the effects, but a similar pattern was observed over time. Female leadership in ministerial roles was no longer statistically significant for left-wing MPs during this period, thus confirming the normalization argument. These results give support to existing research (Murray, 2014; Matland and Studlar 1996; Lovenduski and Norris, 2003; Krook and O'Brien, 2012; Escobar-Lemmon and Taylor-Robinson, 2009) which suggests that leftwing parties are closer to feminist demands and the promotion of gender equality across policy domains. Far left and leftist parties introduced in the late 1980s and early 1990s endorsed gender quotas in the internal functioning of their organizations, and have been more active in promoting women into leadership positions earlier than rightist parties. As a result, the impact of the presence of women in parliament and women's access to leadership positions is less intense in leftist parties.

Finally, the results also vary when controlling for incumbency status (Figure A3 and Table A8). An increasing number of female MPs increases issue attention, but this does not hold for female MPs in the opposition. When looking into incumbency status, results in Figure 5 and Table A6 illustrate that in the case of the governing party, the share of female MPs' issue attention increased as the number of women increased and as women gained access to leadership positions, while the opposite occurred for MPs in the opposition parties. The estimated effect of female leadership in government on female issue attention was positive and significant for MPs in both the opposition and incumbent parties, even though the effect was substantially lower for the opposition. These results indicate that female MPs increase their share of attention when their party is governing, and therefore, during periods in which oversight activities are chiefly aimed at highlighting the merits and benefits associated with government action. In contrast, during periods in which oversight activities are aimed at highlighting the 
problems and flaws of government action, the female share of issue attention declines. These results indicate that the distribution of issue attention between male and female MPs reinforces the traditional role of women in political debates as a more consensual and less aggressive policy actor, with some notable exceptions.

\section{Conclusion}

Female MPs' access to parliamentary debates in Spain is biased. As others have demonstrated for Latin America (Heath et al., 2005), the US (Atkinson, 2020), the UK (Blumenau, 2019), and other European countries (Galligan et al., 2008), the Spanish parliament is a gendered institution that systematically reinforces the underrepresentation of women in high-profile policy domains, especially high-profile issues like economics, foreign affairs and national security. These results also give support to the findings of authors like Krook and O'Brien (2012) and Annesley et al. (2019) regarding the appointment of female cabinets across countries. Women are underrepresented in those policy areas that do not fit into what traditionally is defined as a women's issue, and this bias continues to persist.

This paper also demonstrates that it takes more than increasing the presence of women in parliaments, or appointing women in leadership positions, to reduce the existing gender bias. The results show that women's access to parliamentary debates increases as their presence increases, and as they gain access to leadership positions as chairs of parliamentary committees or as ministers, with important differences across policy areas. Overall, in comparison with male MPs, female MPs ask fewer questions to members of government about highly salient issues like economic recession, terrorist attacks, political corruption and secessionist vindications and, when they do, their interventions take place in parliamentary venues that are less visible to their constituencies. The results also show that an increase in numbers and leadership 
positions facilitates women's access to political debates to a greater extent in the case of incumbent parties. That is, female MPs are less likely to ask oral questions aimed at highlighting the flaws and shortcomings of the governing party, and to participate in those venues that are more rewarding with regard to advancing MPs' political careers. Finally, the results also show that an increase in numbers and leadership positions has a less dramatic effect on female MPs in left-wing parties that implemented gender quotas and other mechanisms to reduce gender inequality in the internal functioning of their organizations in the 1990s.

The capacity of female MPs to act and stand up for women depends not only on increasing the presence of women in parliament, but on transforming the informal norms and the culture of masculinity that still prevails in most political institutions. The informal rules, conventions, processes, practices and behaviour within the Spanish parliament have a gendered nature that puts female MPs at a disadvantage, especially in traditionally masculine issues and those political venues that are more rewarding with regard to advancing MPs' political careers. Further research is needed to assess the added value of female presence in political debates, and especially whether male and female MPs defend different policy positions. By the same token, further research is needed to assess to what extent the gender divide of issue attention also occurs in political scenarios like social media in which policy-makers have more opportunities to overcome existing power arrangements that characterized traditional political institutions. 


\section{References}

Annesley, C., Engeli, I. and Gains, F., 2015. The profile of gender equality issue attention in Western Europe. European Journal of Political Research, 54(3), pp.525-542

Annesley, C., Beckwith, K. and Franceschet, S., 2019. Cabinets, ministers, and gender. Oxford University Press

Atkinson, M. L. 2020. Gender and Policy Agendas in the Post-War House. Policy Studies Journal, 48(1), 133-156.

Atkinson, M.L. and Windett, J.H., 2019. Gender stereotypes and the policy priorities of women in congress. Political Behavior, 41(3), pp.769-789.

Bäck, H., \& Debus, M. 2019. When Do Women Speak? A Comparative Analysis of the Role of Gender in Legislative Debates. Political Studies, 67(3), 576-596.

Bakker, R., Edwards, E., Hooghe, L., Jolly, S., Koedam, F., Kostelka, F. and Zilovic, M., 2020. 2014 Chapel Hill expert survey trend file. Version 1.0. Chapel Hill, NC: University of North Carolina, Chapel Hill. Available at: chesdata. eu (accessed 25 June 2018).

Barnes, T.D. and O'Brien, D.Z., 2018. Defending the realm: The appointment of female defense ministers worldwide. American Journal of Political Science, 62(2), pp.355-368

Baumgartner, Frank, and Bryan Jones .1993. Agendas and Instabilities in American Politics. Chicago: University of Chicago Press.

Baumgartner, F.R., Breunig, C. and Grossman, E. eds., 2019. Comparative policy agendas: Theory, tools, data. Oxford University Press

Blumenau, J. 2019. The Effects of Female Leadership on Women's Voice in Political Debate. British Journal of Political Science, 1-22.

Bratton, Kathleen. 2005. "Critical Mass Theory Revisited: The Behavior and Success of Token Women in State Legislatures." Politics and Gender 1: 97125.

Burns, N. and Gallagher, K., 2010. Public opinion on gender issues: The politics of equity and roles. Annual Review of Political Science, 13, pp.425-443.

Celis, K., Childs, S., Kantola, J. and Krook, M.L., 2008. Rethinking women's substantive representation. Representation, 44(2), pp.99-110.

Celis, K. and Childs, S., 2008. Introduction: The descriptive and substantive representation of women: New directions. Parliamentary Affairs, 61(3), pp.419425

Celis, K., 2012. On substantive representation, diversity, and responsiveness. Politics \& Gender, 8(4), p.524.

Celis, Karen, Sarah Childs, and Jennifer Curtin. 2016. "Specialised parliamentary bodies and the quality of women's substantive representation: a comparative analysis of Belgium, United Kingdom and New Zealand." Parliamentary Affairs 69,4: 812-829

Celis, K. and Lovenduski, J., 2018. Power struggles: gender equality in political representation. European Journal of Politics and Gender, 1(1-2), pp.149-166 
Chaqués Bonafont, Laura, A. Palau and Frank Baumgartner. 2015. Agenda Dynamics in Spain, London: Palgrave

Chaqués Bonafont, Laura and Palau, A.M., 2011. Assessing the Responsiveness of Spanish Policymakers to the Priorities of their Citizens. West European Politics, 34(4), pp.706-730.

Chattopadhyay, R. and Duflo, E., 2004. Women as policy makers: Evidence from a randomized policy experiment in India. Econometrica, 72(5), pp.1409-1443.

Childs, S., 2004. New Labour's Women MPs: Women Representing Women. Routledge.

Cox, Gary W. and Mathew D. McCubbins. 2005. Setting the Agenda: Responsible Party Government in the U.S. House of Representatives. Cambridge University Press.

Dahl, R.A., 1998. On Democracy. New Haven and London.

Dahlerup, D. (1988), From a Small to a Large Minority: Women in Scandinavian Politics. Scandinavian Political Studies, 11: 275-298.

Dahlerup, D., 2006. The story of the theory of critical mass. Politics \& Gender, 2(4), p.511.

Damgaard, E. 1995. How parties control committee members. Parliaments and majority rule in Western Europe, pp.308-325.

Darcy, R., 1996. Women in the state legislative power structure: Committee chairs. Social Science Quarterly, pp.888-898

Delgado, Irene (ed.). 2012. Alcanzando el equilibrio. El acceso y la presencia de las mujeres en los parlamentos, Valencia: Tirant lo Blanc.

Dingler, S.C., Kroeber, C. and Fortin-Rittberger, J., 2019. Do parliaments underrepresent women's policy preferences? Exploring gender equality in policy congruence in 21 European democracies. Journal of European Public Policy, 26(2), pp.302-321.

Döring, Herbert (ed.) (1995) Parliaments and Majority Rule in Western Europe. Frankfurt: Campus Verlag.

Escobar-Lemmon, M. and Taylor-Robinson, M.M., 2009. Getting to the top: Career paths of women in Latin American cabinets. Political Research Quarterly, 62(4), pp.685-699.

Franceschet, S. and Piscopo, J.M., 2008. Gender quotas and women's substantive representation: Lessons from Argentina. Politics \& Gender, 4(3), pp.393-425.

Galligan, Yvonne. 2007. "Gender and political representation: Current empirical perspectives." International Political Science Review 28, no. 5 (2007): 557-570

Galligan, Y., Clavero, S. and Calloni, M., 2008. Gender politics and democracy in postsocialist Europe. Barbara Budrich

Gilardi, F., 2015. The temporary importance of role models for women's political representation. American Journal of Political Science, 59(4), pp.957-970.

Grey, Sandra. 2002. "Does Size Matter? Critical Mass and New Zealand's Women MPs.’Parliamentary Affairs 55: 19-29. 
Heath, Roseanna Michelle, Leslie A. Schwindt-Bayer and Michelle M. TaylorRobinson. 2005. Women on the Sidelines: Women's Representation on Committees in Latin American Legislatures, American Journal of Political Science, Vol. 49, No. 2 (Apr., 2005), pp. 420-436

Jones, M.P., 1997. Legislator gender and legislator policy priorities in the Argentine Chamber of Deputies and the United States House of Representatives. Policy Studies Journal, 25(4), pp.613-629.

Krook, M.L., 2010. Quotas for women in politics: Gender and candidate selection reform worldwide. Oxford University Press.

Krook, M.L. and O'Brien, D.Z., 2012. All the president's men? The appointment of female cabinet ministers worldwide. The Journal of Politics, 74(3), pp.840-855

Lombardo, E. and Meier, P., 2016. The symbolic representation of gender: A discursive approach. Routledge

Lovenduski, J. 2001. "Women and Politics: Minority Representation or Critical Mass? Parliamentary Affairs 54 (4): 743-58.

Lovenduski, J., 2005. Feminizing politics. Polity.

Lovenduski, J. and Norris, P., 2003. Westminster women: the politics of presence. Political studies, 51(1), pp.84-102.

Lovenduski, J., Krook, M. L., \& Squires, J. (2006). Western Europe, North America, Australia and New Zealand: Gender quotas in the context of citizenship models. Routledge

Mansbridge, Jane. 1999. "Should Blacks Represent Blacks and Women Represent Women? A Contingent 'Yes", Journal of Politics 61 (3): 628-57.

Mateo Diaz, Mercedes. 2005. Representing women? Essex: ECPR press

Mattson, I. and Strøm, K., 1995. Parliamentary committees. Parliaments and majority rule in Western Europe, pp.249-307.

Matland R and Donley T. Studlar .1996. The Contagion of Women Candidates in Single-Member District and Proportional Representation Electoral Systems: Canada and Norway, The Journal of Politics 1996 58:3, 707-733

Meier P. 2004. The Mutual Contagion Effect of Legal and Party Quotas: A Belgian Perspective. Party Politics;10(5):583-600.

Norris, P., \& Lovenduski, J. 1995. Political recruitment: Gender, race and class in the British Parliament. Cambridge University Press.

Murray, R. 2014. Quotas for Men: Reframing Gender Quotas as a Means of Improving Representation for All. American Political Science Review, 108(3), 520-532

O’Brien N, D., and Rickne, J. 2016. Gender Quotas and Women's Political Leadership. American Political Science Review, 110(1), 112-126

Osborn, T. and Mendez, J.M., 2010. Speaking as women: Women and floor speeches in the Senate. Journal of Women, Politics \& Policy, 31(1), pp.1-21.

Paxton, Pamela, Sheri Kunovich, Melanie M. Hughes (2007) Gender in Politics. Annual Review of Sociology. 33:1, 263-284 
Phillips, A., 1995. The politics of presence: Issues in democracy and group representation. In Oxford Political Theory. Oxford University Press.

Pitkin, H.F., 1967. The Concept of Representation. University of California Press.

Russo, F., and Wiberg, M.2010. Parliamentary Questioning in 17 European Parliaments: Some Steps towards Comparison. The Journal of Legislative Studies, 16(2): 215.

Saint-Germain, M. 1989. Does Their Difference Make a Difference? The Impact of Women on Public Policy in Arizona Legislature, Social Science Quarterly, 70:956-968

Saward, M., 2008. Representation and democracy: revisions and possibilities. Sociology compass, 2(3), pp.1000-1013.

Schwindt-Bayer, L.A. and Mishler, W. 2005. An Integrated Model of Women's Representation. Journal of Politics, 67: 407-428.

Studlar, D.T. and Moncrief, G.F., 1999. Women's work? The distribution and prestige of portfolios in the Canadian provinces. Governance, 12(4), pp.379-395

Taylor-Robinson, Michelle M. \& Roseanna Michelle Heath (2003) Do Women Legislators Have Different Policy Priorities than Their Male Colleagues? Women \& Politics, 24:4, 77101, DOI: https://doi.org/10.1300/J014v24n04_04

Thomas, Sue. 1991. "The Impact of Women on State Legislative Policies.". The Journal of Politics. 4: 958-976.

Thomas, Sue. 1994. How Women Legislate. New York: Oxford University Press.

Verge, T. 2008. Cuotas voluntarias y legales en España. La paridad a examen. Revista española de Investigaciones Sociológicas, 123:123-150.

Verge, T., \& de la Fuente, M. 2014. Playing with different cards: Party politics, gender quotas and women's empowerment. International Political Science Review, 35(1), 67-79.

Wängnerud, Lena 2009. Women in Parliaments: Descriptive and Substantive Representation. Annual Review of Political Science, 12:51-69.

Welzel, C., Norris, P., \& Inglehart, R. (2002). Gender equality and democracy. Comparative Sociology, 1(3-4), 321-345

Waylen, G., Celis, K., Kantola, J. and Weldon, L. eds., 2013. The Oxford handbook of gender and politics. Oxford University Press 


\section{Footnotes}

${ }^{\mathrm{i}}$ We would like to thank the great comments and suggestions of the reviewers which
have contributed to make this article stronger. Also, we thank Yeimy Ospina for
excellent research assistance in this project and other members of the Quality of
Democracy Research Group (www.q-dem.org). Finally, we are grateful for the
comments received on previous versions of this article at the research seminars of the
IBEI and the UB, the Comparative Agendas Project annual Conference in Budapest and
the ICPP4 in Montreal.

ii The dataset has been developed by the Quality of Democracy Research Group, and it is available at www.q-dem-com. Note the 11th legislature is empty in this dataset, as no oral questions were actually asked during this term. The 11th legislature ran from 20 December 2015 to 26 June 2016. During these 11 months, parliamentary groups were unable to elect a new prime minister. Therefore, the previous conservative government, led by PP leader Mariano Rajoy, remained in office. During Rajoy's mandate, when he was acting prime minister, no oral questions were asked during the plenary sessions.

iii See the rules of the Congreso de los Diputados article 185 to 190, and the Resoluciones de la Presidencia del Congreso de los Diputados sobre el desarrollo del artículo 188 del reglamento del Congreso. As far the allotment of questions is proportional to the number of seats, the governing party had always the largest allocation of questions, with a minor exception. After winning the motion of no confidence in June 2018, the governing party (PSOE) had a smaller allocation of oral questions than the PP. This situation ended after the call for a general election in April 2019.

${ }^{\text {iv }}$ Committee names vary according to the multiple issues within the major issue topic and in reference to the name of the ministries for each cabinet. For example, the economy topic in our sample includes twelve committees with multiple subtopics: Comisión de Economía, Comercio y Hacienda, Comisión de Presupuestos, Comisión Mixta para las Relaciones con el Tribunal de Cuentas, Comisión de Economía y Hacienda, Comisión de control de los créditos destinados a gastos reservados, Comisión de Hacienda y Administraciones Públicas, Comisión de Economía y Competitividad, Comisión de Presupuestos, Comisión de Hacienda y Función Pública, Comisión de Economía, Industria y Competitividad, Comisión de Hacienda, and Comisión de Economía y Empresa

${ }^{v}$ The committee of the Rules of the Congreso de los Diputados has one vice-chair (art. 48 of the rules of Congreso de los Diputados).

${ }^{\mathrm{vi}}$ We imputed the value of Izquierda Unida (2.0183) for Podemos and the Unidos Podemos regional divisions, as they have entered the European, national and regional elections as a single party since 2015 . 